\title{
The Music Products Industry as Part of a Collegiate Music Industry Program Curriculum
}

\author{
Andrew Surmani \\ California State University, Northridge \\ Carl Anderson \\ Bradley University
}

This paper was presented at the 2018 International Summit of the

Music \& Entertainment Industry Educators Association

March 22-24, 2018

https://doi.org/10.25101/18.22

\section{Abstract}

This study examines the inclusion of the Music Products Industry as part of an overall collegiate Music Industry Program curriculum. Historically, most music industry curriculums have focused heavily on topics such as recording, live performance, music publishing, music licensing, music and media, and artist management. While some of these traditional music fields have seen wide-sweeping changes in their business models in recent years, the music products industry has continued to be a relatively steady and significantly relevant part of the overall industry, with many job opportunities for music industry graduates. However, coursework reflecting this portion of the industry is often underrepresented or even completely absent from many curricula. This study defines what the music products industry is and its component parts, and then examines through two research studies the curriculum of many collegiate music business programs and the needs identified by both retailers and manufacturers of the music products industry sector related to the skills and knowledge they are looking for in employee candidates.

Keywords: acoustic guitars, acoustic pianos, amplifiers, basses, cables, computer music products, digital pianos, effects, electric guitars, fretted instruments, NAMM, GenNext, general accessories, internships, microphones, multitrack recorders, music products, music business, music industry, percussion, print music, pro audio, recording technology, school music, sound and lighting, ukuleles, wind instruments, music business curriculum, collegiate music degrees
Andrew Surmani is Associate Professor of Music Industry Studies and serves as the Academic Lead of the Master of Arts in Music Industry Administration degree program at California State University, Northridge. Andrew has worked for more than 30 years in the music industry. Prior to joining the CSUN faculty, Andrew worked for more than 29 years for Alfred

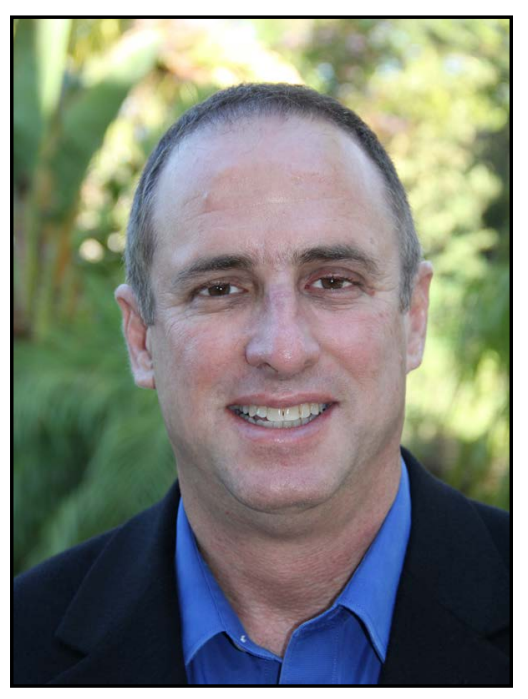
Music, as Chief Marketing Officer overseeing global sales, marketing, and product development. While at Alfred Music he helped launch some of the company's most successful product lines. He currently serves as the CEO of Caleb Chapman's Soundhouse (www.ccsoundhouse.com), a contemporary music performance studio in Utah that will be franchised all over the world. A co-author of the best-selling series, Alfred's Essentials of Music Theory and the newly published Copyright Handbook for Music Educators and Directors, Andrew has also published articles in educational and music industry journals, and has conducted workshops on music education and industry topics throughout the world. Andrew also works as a freelance musician, and has performed in the Montreux (Switzerland), Istanbul (Turkey), Juan-les-Pins (France), Jazz à Vienne (France), Umbria (Italy), Lake Biwa (Japan), San Sebastian (Spain), and Wigan (England) international jazz festivals. He has performed in the concert halls of Carnegie Hall, Avery Fisher Hall, and Alice Tully Hall at Lincoln Center. Additionally, he led a band and played lead trumpet in two shows at 
Walt Disney World, and also managed high school groups on tour to Hawaii and Japan for a music production company. Andrew was a founding board member and past president of the Jazz Education Network (JEN). In addition, he served on the Music Technology Advisory Board at Indiana University/Purdue University Indianapolis (IUPUI), and the Technology through Music Education (TI:ME) Advisory Board.

Carl Anderson directs the Music Business and Music and Entertainment Industry programs at Bradley University in Peoria, Illinois. Established in 1948, Bradley's Music Business program boasts as the oldest program in the country. Mr. Anderson spent 28 years in private industry in the music products sector managing Kidder Music Service, Inc., one of the largest music retailers in the country. Under his direction, Kidder Music was frequently honored in the top 100 music retailers in the country. He has recently authored a book entitled The Music Products Industry: A Textbook for Music Business Students. Mr. Anderson is an active commercial trombone player and has performed for many groups, from the Lawrence Welk All-Stars to the Temptations. Mr. Anderson is the founder of the Central Illinois Jazz Orchestra and the leader of the Carl Anderson New Orleans Jazz Band, which has produced and recorded three separate albums. $\mathrm{He}$ is also in the horn line for the popular rock/funk group, J.C. \& The Redemption. Additionally, he is a member of the Prairie Wind Ensemble where he has served as trombonist, soloist, and guest conductor.

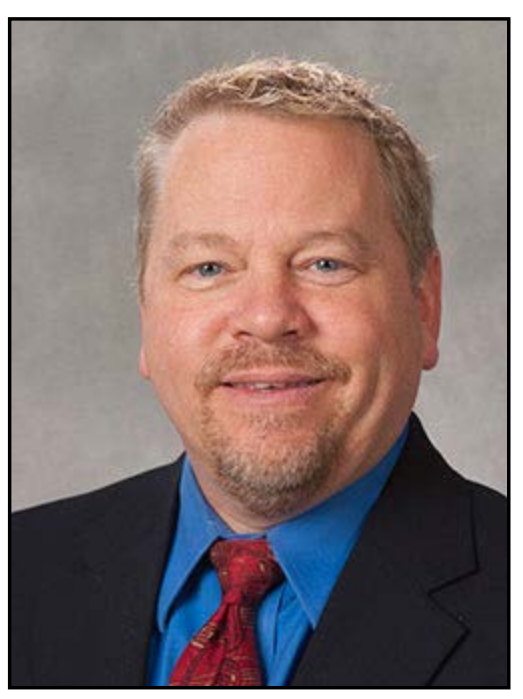




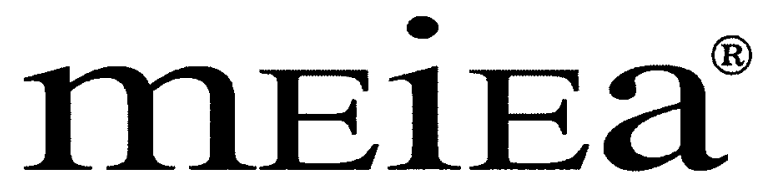

MUSIC \& ENTERTAINMENT INDUSTRY

EDUCATORS ASSOCIATION

\section{PROCEEDINGS OF THE \\ 2018 INTERNATIONAL SUMMIT}

OF THE

\section{MUSIC \& ENTERTAINMENT INDUSTRY EDUCATORS \\ ASSOCIATION}
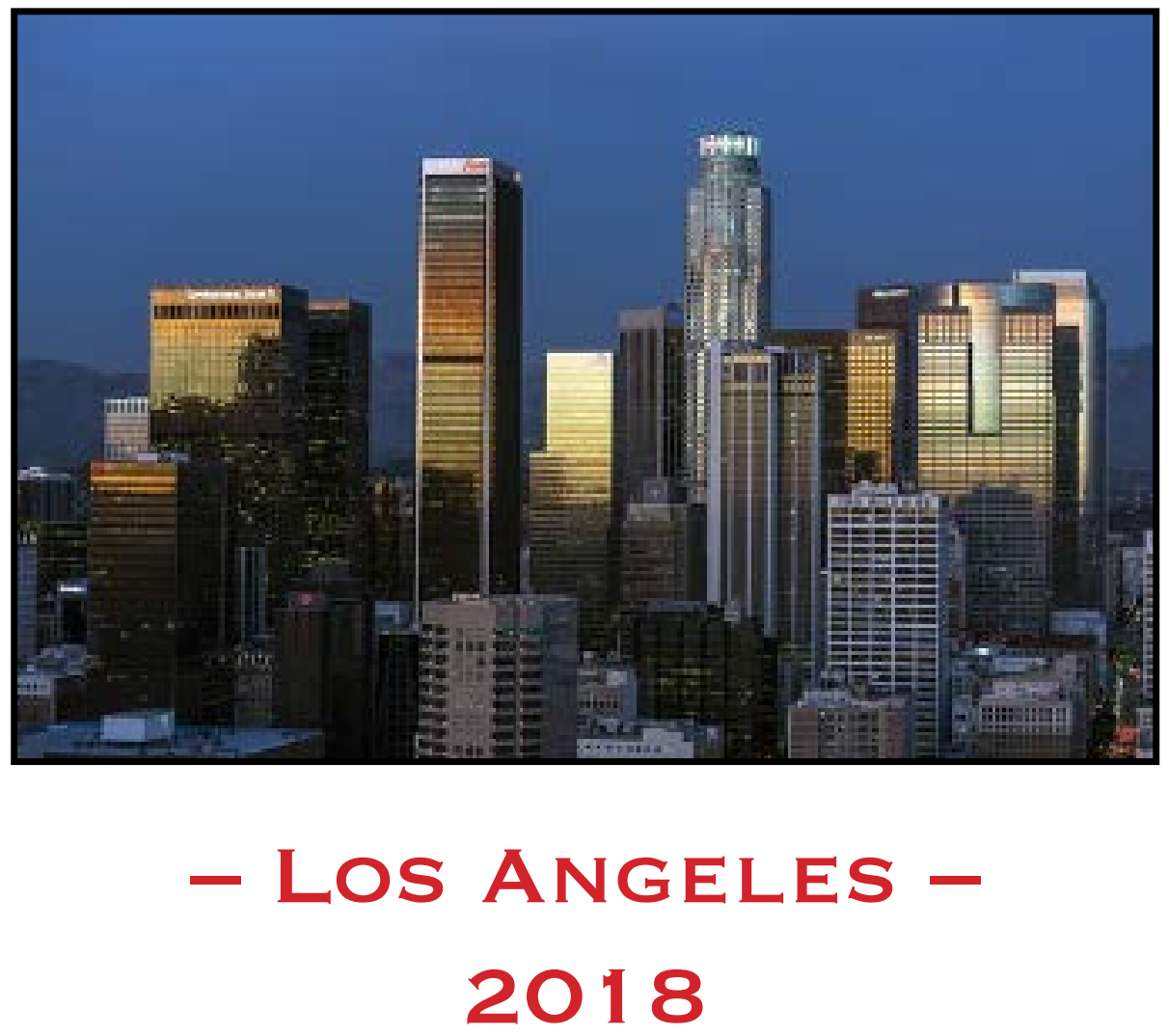

March 22 - 24, $2018 \cdot$ Embassy Suites by Hilton - Los Angeles/Glendale 